\title{
Studi Fenomenologis tentang Pengalaman Kesepian dan Kesejahteraan Subjektif pada Janda Lanjut Usia
}

\author{
Lucky Ade Sessiani \\ Fakultas Psikologi dan Kesehatan \\ UIN Walisongo Semarang \\ email: lucky_sessiani@walisongo.ac.id
}

\begin{abstract}
Elderly women experience loneliness related to unexpected situations of partner loss (husband's death). Loneliness can have an impact on subjective well-being, life satisfaction, quality of life, mental and physical health, and even death. The purpose of this study was to describe and understand experiences related to loneliness for elderly widows. The subjects involved were 6 (six) widows due to the death of their husbands (widowed), widows of more than 1 year, and no history of psychological disorders. Methods of data collection using interviews and observation. This study resulted in the conclusion that an elderly widow can experience loneliness due to the loss of a spouse who is taken away by death. Subjective well-being and perceived life satisfaction are the results of a religious coping strategy that is effective in overcoming loneliness experienced. When feelings of losing a spouse can be overcome by religious behavior, enthusiasm for survival and re-establishing social interaction, the elderly can feel well-being and life satisfaction.
\end{abstract}

\section{Keywords: $\quad$ subjective well-being; loneliness; elderly widow; older people}

\begin{abstract}
Abstrak: Perempuan lansia mengalami kesepian berkaitan dengan situasi kehilangan pasangan yang tidak terduga (kematian suami). Kesepian dapat berdampak pada kesejahteraan subjektif, kepuasan hidup, kualitas hidup seseorang, kesehatan mental dan fisik, bahkan kematian. Tujuan penelitian ini adalah untuk mendeskripsikan dan memahami pengalaman yang berkaitan dengan kesepian bagi janda lanjut usia. Subjek yang terlibat sebanyak 6 (enam) orang berstatus janda akibat ditinggal mati suami (cerai mati), sudah menjanda lebih dari 1 tahun, dan tidak memiliki riwayat gangguan psikologis. Metode pengumpulan data menggunakan wawancara dan observasi. Penelitian ini menghasilkan suatu kesimpulan bahwa seorang janda lansia dapat mengalami kesepian akibat kehilangan pasangan hidup yang terenggut oleh kematian. Kesejahterana subjektif dan kepuasan hidup yang dirasakan adalah hasil dari strategi coping religius yang efektif dalam mengatasi kesepian yang dialami. Ketika perasaan kehilangan pasangan hidupdapat diatasi dengan perilaku religius, semangat untuk bertahan hidup dan menjalin kembali interaksi sosial, maka lansia dapat merasakan kesejahteraan dan kepuasan hidup.
\end{abstract}

Kata Kunci: kesejahteraan subjektif; kesepian; janda; lanjut usia 


\section{A. Pendahuluan}

Menurut Peraturan Pemerintah Republik Indonesia Nomor 43 Tahun 2004 dan UU No. 13/Tahun 1998 tentang Kesejahteraan Lansia, lanjut usia adalah seseorang yang telah mencapai usia 60 (enam puluh) tahun ke atas. Komposisi penduduk tua bertambah dengan pesat baik di negara maju maupun negara berkembang, hal ini disebabkan oleh penurunan angka fertilitas (kelahiran) dan mortalitas (kematian), serta peningkatan angka harapan hidup (life expectancy), yang mengubah struktur penduduk secara keseluruhan. Proses terjadinya penuaan penduduk dipengaruhi oleh beberapa faktor, misalnya: peningkatan gizi, sanitasi, pelayanan kesehatan, hingga kemajuan tingkat pendidikan dan sosial ekonomi yang semakin baik. Secara global populasi lansia diprediksi terus mengalami peningkatan, bahkan di Asia dan Indonesia dari tahun 2015 sudah memasuki era penduduk menua (aging population) karena jumlah penduduknya yang berusia 60 tahun ke atas (penduduk lansia) melebihi angka 7\%. ${ }^{1}$

Data dari Pusat Data dan Informasi Kementerian Kesehatan RI menunjukkan bahwa pada tahun 2017 terdapat 23,66 juta jiwa penduduk lansia di Indonesia (9,03\%). Berdasarkan data proyeksi penduduk dunia yang dikeluarkan oleh PBB, diprediksi jumlah penduduk lansia di Indonesia pada tahun2020 (27,08 juta), tahun 2025 (33,69 juta),tahun 2030 (40,95 juta) dan tahun 2035(48,19 juta). ${ }^{2}$ Sementara itu, data dari Badan Pusat Statistik (BPS) Provinsi Jawa Tengah menunjukkan pada tahun 2016 bahwa jumlah penduduk lansia sebesar 12,18\% dari jumlah total penduduk di Provinsi Jawa Tengah, dan jumlah ini tercatat terus menunjukkan peningkatan selama kurun waktu 5 tahun terakhir. ${ }^{3}$ Persentase jumlah penduduk lansia sebesar 9,03\% (lebih dari 7\%) dari jumlah keseluruhan penduduk menunjukkan bahwa Indonesia termasuk negara dengan struktur penduduk menuju tua (aging population).

\footnotetext{
1Badan PusatStatistik Provinsi Jawa Tengah, "Profil Lansia Jawa Tengah 2016” (Semarang: Badan Pusat Statistik Provinsi Jawa Tengah, 2017), https://jateng.bps.go.id/publication/ 2017/08/22/198c042d53836d78c3e51277/profil-lansia-jawa-tengah--2016.html.

${ }^{2}$ Pusat Data dan Informasi Kementerian Kesehatan Republik Indonesia, Analisis Lansia di Indonesia (Jakarta: Kementerian Kesehatan RI, 2017), http://www.pusdatin.kemkes.go.id/ resources/download/pusdatin/lain-lain/Analisis Lansia Indonesia 2017.pdf.

3Badan Pusat Statistik Provinsi Jawa Tengah, "Profil Lansia Jawa Tengah 2016."
} 
Masyarakat luas seringkali masih memberikan persepsi negatif terhadap keberadaan lansia. Komunitas masyarakat berusia di atas 60 tahun ini sering dianggap tidak berdaya, sakit-sakitan, tidak produktif, dan sebagainya. Tak jarang mereka diperlakukan sebagai beban keluarga, masyarakat, hingga negara. Mereka sering tidak disukai serta sering dikucilkan di panti-panti jompo. Persepsi negatif ini muncul karena melihat lanjut usia hanya dari kasuskasus lanjut usia jompo yang amat tergantung dan sakit-sakitan, padahal persepsi ini belum tentu benar sebab cukup banyak lansia sekitar 60 tahun ke atas masih dapat berperan aktif dalam keluarga dan masyarakat sekitarnya. Data dari Badan Pusat Statistik tahun 2015 menunjukkan bahwa 90,99\% penduduk lansia berjenis kelamin laki-laki di Indonesia masih berperan aktif sebagai kepala rumah tangga yang memenuhi kebutuhan keluarga sehari-hari. Rasio ketergantungan penduduk Indonesia tahun 2015 sebesar 13,28\% menunjukkan bahwa dari setiap 100 orang penduduk usia produktif menanggung sekitar 14 orang penduduk lansia. ${ }^{4}$ Angka perbandingan yang masih wajar terjadi di negara berkembang dengan populasi lansia yang cukup tinggi. Hal ini menunjukkan bahwa masih banyak lansia di Indonesia yang berdaya dan mandiri secara finansial.

Di Provinsi Jawa Tengah, rasio jenis kelamin penduduk lansia menunjukkan dominasi lansia perempuan, yaitu sebesar $87,35 \%$ dari jumlah seluruh penduduk lansia. Dilihat dari status perkawinan, sejumlah 59,19\% dari lansia perempuan di Jawa Tengah berstatus single (belum menikah, cerai mati, dan cerai hidup) dan 70,50\% di antaranya tidak pernah sekolah. Profil ini menunjukkan bahwa lansia perempuan lebih rentan baik dari segi finansial, sosial, maupun emosional. ${ }^{5}$

Pengaruh proses ketuaan akan menimbulkan berbagai masalah sebab usia tua adalah periode penutup dalam rentang hidup seseorang. Periode penutup yaitu periode di mana seseorang telah beranjak jauh dari periode terdahulu yang lebih menyenangkan, menjadikan lansia sering melihat ke masa

${ }^{4}$ Badan Pusat Statistik Provinsi Jawa Tengah. 
lalu dan cenderung ingin hidup pada masa itu dan mengabaikan masa depan. ${ }^{6}$ Erik H. Erikson memandang masa lansia sebagai fase terakhir dalam tahap perkembanganyang ditandai dengan terjadinya konflik antara keutuhan dan keputusasaan (ego integrity vs despair).? Individu harus mencoba menyeimbangkan antara pencarian integritas dan perasaan putus asa. Keluar dari konflik ini berarti menghasilkan kebijaksanaan. Seseorang harus mampu meninjau ulang hidupnya, melakukan penalaran, dan mengikat kembali ujungujung yang lepas (mengintregrasikannya) lalu menghasilkan pandangan positif akan lebih mudah menjalani hidup dalam ketenangan dan mencerminkan keutuhan. Sementara sebaliknya, putus asa akan menghasilkan kondisi neurotik di mana seseorang tidak bisa memperbaiki kegagalannya, merasa kecewa akan hidupnya. ${ }^{8}$ Kondisi ini akansemakin kuat apabila lansia menghadapi dampak negatif kesepian yang dihasilkan akibat kematian pasangan hidup.

Robert Havighurst menyebutkan 6 tugas perkembangan bagi usia lanjut yang menentukan terbentuknya keadaan terbaik (well-being) dari seseorang, yang dilihat dari sejauh mana ia mampu melewati tiap-tiap peristiwa dalam perkembangan yang sebagian besar mengenai isu keterpisahan (disengagement).9 Tugas-tugas perkembangan tersebut adalah: 1) Menyesuaikan diri dengan penurunan kekuatan fisik dan kesehatan. 2) Menyesuaikan diri dengan pensiun dan pengurangan penghasilan. 3) Menyesuaikan diri dengan kematian pasangan hidup. 4) Membentuk hubungan yang eksplisit dengan kelompok usia sebaya. 5) Mengambil dan menyesuaikan diri dengan peran sosial secara fleksibel. 6) Membuat pengaturan hidup (aktivitas) yang memuaskan secara fisik.

Lansia menyesuaikan diri dengan penurunan fisik dan kesehatan melalui keinginan mereka yang besar untuk mandiri, hal ini menjadikan sebagian lansia takut menjadi tergantung dengan orang-orang terdekatnya. Namun kenyataan-

${ }^{6}$ Elizabeth B. Hurlock, Psikologi perkembangan: Suatu pendekatan sepanjang rentang kehidupan, ed. oleh Ridwan Max Sijabat, 5 ed. (Jakarta: Erlangga, 2002), 380.

7John W. Santrock, Life-span Development, Jilid 2 (Jakarta: Erlangga, 2002), 43.

${ }^{8}$ K.Warner Schaie dan Sherry L Willis, Adult Development and Aging (New York: Harper Collins Publisher, Inc, 1991), 87.

${ }^{9}$ Schaie dan Willis, 87-88. 
nya, ketergantungan menjadi isu yang sering muncul pada diri lansia. Ketergantungan (dependency) pada kehidupan lansia dapat terjadi dalam hal finansial, fisik dan emosional. ${ }^{10}$ Peristiwa-peristiwa seperti pensiun, penyakit yang membuat mereka sulit beraktivitas, dan kematian pasangan merupakan sumber masalah pencetus konsep ketergantungan yang dimaksud. Ketergantungan terutama secara fisik terjadi begitu parah hanya pada beberapa kasus tertentu seperti penyakit hingga harus mengadakan institusionalisasi pada lansia (dititipkan di panti atau dirawat di rumah sakit).

Meskipun lansia memerlukan kepercayaan diri secara fisik dan finansial, mereka tetap tidak suka sendirian meskipun nyatanya, banyak ditemukan lansia yang hidup sendiri.11 Lansia hidup sendiri pasca kematian pasangan hidupnya, terjadi baik pada lansia laki-laki maupun perempuan. Mereka memilih hidup sendiri sebagian besar karena alasan tidak mau merepotkan anak-anaknya yang sudah berkeluarga. Orang lanjut usia, bagaimanapun memerlukan kasih sayang, afeksi, dan interaksi sosial seperti orang pada umumnya. Jika pasangan hidup meninggal, kebutuhan-kebutuhan ini akan sulit dipenuhi. Respon emosional terhadap kondisi ini adalah kesepian, dan selanjutnya mengarah pada ketergantungan secara fisik yang menjadi ketakutan terbesar sebagian besar lansia. Kesepian pada lansia umumnya terjadi akibat kematian pasangan, namun juga bisa terjadi akibat faktor kontekstual seperti tinggal di kota besar. Janda yang tinggal di kota lebih sering merasa kesepian dibanding mereka yang tinggal di desa dengan ikatan kekeluargaan yang kuat. ${ }^{12}$ Van Baarsen menambahkan bahwa kesepian pada lansia diakibatkan keterpisahannya dengan anak-anak yang tinggal di tempat lain bersama keluarganya. ${ }^{13}$

Kesepian merupakan suatu masalah yang berkaitan dengan ketergantungan, karena seiring berjalannya usia orang akan semakin membutuhkan respon emosional dari keluarganya. Lansia sangat suka berbicara, berdiskusi

\footnotetext{
${ }^{10}$ Schaie dan Willis, 89.

${ }^{11}$ Schaie dan Willis, 93.

${ }^{12}$ Schaie dan Willis.

${ }^{13}$ Spencer A. Rathus dan Jeffrey S. Nevid, Psychology and the Challenges of Life: Adjustment in The New Millenium (New York: John Wiley \& Sons, Inc., 2002), 403.
} 
tentang politik terkini, menceritakan pengalamannya dan dikaitkan dengan masalah-masalah aktual. Pada siapa mereka bisa berbicara? Keadaan semakin menjauhkan mereka dari anak-anak yang sudah dewasa. menurut pandangan lansia, keberadaan mereka hanyalah "beban" bagi keturunan yang mereka cintai. Oleh karenanya, agar tidak menjadi pengganggu, mereka memilih hidup sendiri dalam kesepian. ${ }^{14}$

Kesepian menurut Perlman \& Peplau diartikan sebagai suatu kesenjangan antara harapan dan kenyataan yang dirasakan oleh seseorang tentang tingkat hubungan sosial yang dimiliki. Seorang individu mengalami kesepian apabila tidak mampu membangun kedekatan dalam hubungan interpersonal seperti yang diharapkannya. ${ }^{15}$ Dengan kata lain, kesepian muncul ketika individu merasa hubungan sosial yang dijalaninya saat ini kurang memuaskan. Hulme memandang kesepian sebagai penderitaan jiwa yang bersumber dari keterpisahannya dengan orang lain yang disebabkan keunikan dan kekhususan yang dimiliki seseorang. Kesepian dirasakan secara subjektif, sangat tergantung oleh individu yang merasakannya. Karena bisa saja seseorang merasakan kesepian di tengah suasana yang ramai. ${ }^{16}$ David 0 . Sears mengemukakan definisinya mengenai kesepian sebagai suatu kegelisahan subjektif yang dirasakan seseorang ketika hubungan sosial kehilangan ciri-ciri pentingnya. Situasi kehilangan ini dapat terjadi secara kuantitatif maupun kualitatif. Secara kuantitatif dalam arti jika seseorang hanya memiliki sedikit teman, bahkan tidak sama sekali. Kesepian terjadi secara kualitatif apabila seseorang merasa hubungan yang dijalinnya dengan orang lain terlalu dangkal, kurang memuaskan seperti apa yang diharapkannya. ${ }^{17}$

Kesepian pada lansia dapat disebabkan oleh adanya kecenderungan pergeseran model keluarga di Indonesia dari bentuk extended family (keluarga

${ }^{14}$ Schaie dan Willis, Adult Development and Aging, 93-5.

${ }^{15}$ Lena Dahlberg, Neda Agahi, dan Carin Lennartsson, "Lonelier than ever? Loneliness of older people over two decades," Archives of Gerontology and Geriatrics 75 (2018): 96-103, https://doi.org/ 10.1016/J.ARCHGER.2017.11.004.

${ }^{16}$ W. Hulme, Kesepian Sumber Ilham yang Kreatif, terj. Staf Yayasan CLK (Jakarta: Cipta Loka Karya, 1993), 22.

${ }^{17}$ David O. Sears, Jonathan L. Freedman, dan L. Anne Peplau, Psikologi Sosial, terj. oleh Michael Adryanto dan Savitri Soekrisno (Jakarta: Erlangga, 1999), 212. 
luas) menjadi nuclear family (keluarga inti), yang untuk kaum muda diartikan sebagai keluasan dalam belajar dan berkarier serta membangun keluarga secara mandiri dan jauh dari orangtua. Seiring bertambahnya usia, anak, teman, dan orang-orang terdekat semakin sibuk. Sang anak dengan keluarga intinya menjadi kurang memperhatikan orangtua, dan jalinan komunikasi semakin berkurang. ${ }^{18}$ Akibatnya, banyak lansia yang terpaksa maupun secara sadar memilih untuk menjalani hidup sendiri, mencari aktivitas yang bersifat privacy dan melepaskan ketergantungan pada anak-anaknya.

Selain perubahan pola keluarga, terdapat beberapa faktor lain yang menjadi pemicu timbulnya kesepian. Hasil penelitian Dahlberg menunjukkan bahwa perempuan lebih banyak menyatakan dirinya mengalami kesepian dibandingkan laki-laki. Kondisi yang menjanda baik pada laki-laki maupun perempuan menjadi faktor penting yang memunculkan kesepian, terlebih pada janda akibat ditinggal mati, hal ini menjadi faktor pemicu yang sangat kuat. Lebih lanjut dijelaskan bahwa kondisi menjanda dapat mengakibatkan lansia kurang mendapatkan dukungan sosial dan menghindari kontak sosial. Faktor lain yang dapat memicu kesepian pada lansia adalah kondisi kesehatan yang buruk sehingga membatasi kehidupan sosial yang semula lebih aktif. Kesehatan mental, dalam hal ini tekanan psikologis juga berhubungan erat dengan kesepian karena membuat lansia mempersepsi dunia penuh ancaman sehingga ia mengembangkan perilaku maladaptif yang memicu timbulnya perasaan kesepian. ${ }^{19}$

Menyikapi persepsi masyarakat mengenai keberadaan lansia, dan masih banyak ditemukannya lansia yang hidup dalam kesepian lalu timbul pertanyaan, bagaimana para lansia memandang kehidupannya? Kemudian apa pengaruh cara pandang lansia tersebut terhadap cara mereka menyikapi kehidupannya kini? Akan sangat bermanfaat jika sejak dini kesepian pada masa lansia dapat diidentifikasi. Barangkali dapat dimulai dengan mengenali keadaan yang membentuk konsep kesepian tersebut. Dari sejumlah lansia yang hidup di

\footnotetext{
${ }^{18}$ Nanik Afida, S. Wahyuningsih, dan E. M. Sukamto, "Hubungan antara pemenuhan kebutuhan berafiliasi dengan tingkat depresi pada lansia di Panti Wredha," Anima: Indonesian Psychology Journal 15, no. 2 (2000): 180-195.

${ }^{19}$ Dahlberg, Agahi, dan Lennartsson, "Lonelier than ever? Loneliness of older people over two decades." 101.
} 
sekitar kita, pasti ada beberapa di antaranya yang sering merasakan sepi dalam hidupnya, dapat disebabkan oleh hal yang sama atau berbeda, namun yang pasti akan berdampak secara fisik maupun psikologis. Dampak terhadap kesepian tersebut dapat dipicu oleh cara lansia menyikapinya, apakah secara positif atau negatif.

Sikap dan penilaian seseorang terhadap peristiwa hidup yang ia alami baik secara positif maupun negatif menentukan tingkat kesejahteraan subjektif yang dimilikinya. Kesejahteraan subjektif (subjective well being) atau kebahagiaan subjektif (subjective happiness) adalah penilaian subjektif mengenai apakah seseorang bahagia atau tidak. Penilaian ini termasuk bagaimana seseorang mempersepsi, menginterpretasi, memunculkan kembali, dan benarbenar mengalami peristiwa hidup secara positif atau negatif. ${ }^{20}$ Diener menyatakan bahwa kesejahteraan subjektif adalah kategori fenomena yang sangat luas, melibatkan respon emosional dan penilaian global seseorang mengenai kepuasan hidup. Perasaan sejahtera atau bahagia adalah komponen utama kualitas hidup positif seseorang. ${ }^{21}$ Penelitian terdahulu menunjukkan bahwa keterhubungan sosial (social connectedness) berhubungan secara positif dengan harga diri (self esteem), kepuasan hidup, efikasi diri, kesejahteraan sosial, dan kesehatan mental. Sebaliknya, keterhubungan sosial berhubungan secara negatif dengan sifat kecemasan, kesulitan dalam menyesuaikan diri, depresi, dan munculnya gagasan bunuh diri.22

Tujuan penelitian fenomenologis ini adalah untuk mendeskripsikan dan memahami makna kesepian dan mengetahui sejauh mana para janda lanjut usia merasakan kesejahteraan subjektif. Mendeskripsikan dan memahami mengandung arti antara lain untuk mengetahui asal-mula kesepian terjadi pada diri janda lanjut usia, bagaimana hal tersebut memberikan pengaruh dalam melaksanakan aktivitasnya, dan bagaimana janda lansia mengarahkan daya

\footnotetext{
${ }^{20}$ Seydi Ahmet Satici, Recep Uysal, dan M. Engin Deniz, "Linking social connectedness to loneliness: The mediating role of subjective happiness," Personality and Individual Differences, 2016, 306-10, https://doi.org/10.1016/j.paid.2015.11.035. 680.

${ }^{21}$ P. A. Linley dan P. Joseph, Positive Psychology in Practice (New Jersey: John Wiley \& Sons, 2004),

${ }^{22}$ Satici, Uysal, dan Deniz, "Linking social connectedness to loneliness: The mediating role of subjective happiness."
} 
dan upaya untuk mengatasi kesepian yang dialaminya, hingga mengetahui sejauh mana tingkat kesejahteraan subjektif yang dimiliki.

Secara teoretis, penelitian ini diharapkan dapat memberi manfaat sebagai kajian bagi peneliti bidang psikologi perkembangan, terutama perkembangan pada masa lanjut usia; psikologi sosial, dan psikologi positif. Kesepian merupakan salah satu fenomena yang berkaitan dengan kehidupan sosial yang dialami seseorang dalam tahap perkembangan lansia. Sementara kesejahteraan subjektif merupakan variabel utama yang diteliti dan dipelajari di dalam psikologi positif. Secara praktis, penelitian ini diharapkan bermanfaat bagi: 1) Para janda lanjut usia khususnya, dan para lansia pada umumnya agar dapat memandang kesepian secara lebih positif, menemukan strategi coping yang efektif, dan mengarahkan pada perasaan sejahtera dan bahagia. 2) Masyarakat pada umumnya, agar lebih memperhatikan lansia, memfasilitasi mereka untuk dapat berfungsi baik di tengah masyarakat. 3) Badan pemerintah yang terkait dengan penanganan masalah lansia, untuk dapat lebih memperhatikan kebutuhan lansia serta memberi wadah untuk para lansia yang ditelantarkan oleh keluarganya. 4) Peneliti-peneliti lain yang berminat mengadakan studi lanjut terhadap lansia di Indonesia atau bahkan di seluruh belahan dunia, untuk lebih memusatkan kajian penelitian pada peningkatan kualitas hidup lansia.

Lingkup permasalahan yang diteliti adalah fenomena kesepian pada janda lanjut usia. Fokus penelitian adalah pada pengalaman kesepian yang dialami dan tingkat kesejahteraan subjektif janda lansia. Pengalaman kesepian ini mulamula diungkap dengan memperoleh gambaran bagaimana janda lansia memandang hidupnya pasca kematian suami, apa yang dialami pasca kematian suami, dalam situasi seperti apakah kesepian muncul, dan bagaimana janda lansia mengatasi kesepian yang dialaminya. Sebagai bagian dari dampak kesepian yang dialami, peneliti ingin mengetahui sejauh mana janda lansia merasakan kebahagiaan (kesejahteraan subjektif).

Pengambilan subjek (sampling) secara purposif (purposive sampling). Jumlah subjek yang terlibat sebanyak 6 (enam) orang. Karakteristik subjek adalah perempuan, berusia lanjut (dewasa akhir), berstatus janda akibat ditinggal mati suami (cerai mati), sudah menjanda lebih dari 1 tahun, tidak memiliki riwayat gangguan psikologis, dan bersedia menjadi subjek penelitian. Karakteristik dari keenam partisipan dijelaskan di dalam Tabel 1. 
Tabel 1. Karakteristik Subjek

\begin{tabular}{|c|c|c|c|c|c|c|}
\hline Karakteristik & $\begin{array}{c}\text { Subjek } 1 \\
\text { (Kr) }\end{array}$ & $\begin{array}{c}\text { Subjek } 2 \\
\text { (Ка) }\end{array}$ & $\begin{array}{c}\text { Subjek } 3 \\
\text { (R) }\end{array}$ & $\begin{array}{c}\text { Subjek } 4 \\
\text { (S) }\end{array}$ & $\begin{array}{c}\text { Subjek } 5 \\
\text { (Z) }\end{array}$ & $\begin{array}{c}\text { Subjek } 6 \\
(\mathrm{Ku})\end{array}$ \\
\hline Usia & 79 tahun & 85 tahun & 70 tahun & 74 tahun & 64 tahun & 76 tahun \\
\hline Status janda & cerai mati & cerai mati & cerai mati & cerai mati & cerai mati & cerai mati \\
\hline $\begin{array}{l}\text { Penyebab } \\
\text { suami } \\
\text { meninggal }\end{array}$ & sakit & sakit & Sakit & sakit & sakit & sakit \\
\hline $\begin{array}{l}\text { Lama } \\
\text { menjanda }\end{array}$ & 8 tahun & 42 tahun & 10 tahun & 24 tahun & 6 tahun & 25 tahun \\
\hline $\begin{array}{l}\text { Status } \\
\text { sosioekonomi }\end{array}$ & menengah & menengah & menengah & menengah & menengah & menengah \\
\hline Tempat tinggal & $\begin{array}{l}\text { bersama } \\
\text { cucu }\end{array}$ & $\begin{array}{l}\text { bersama } \\
\text { anak }\end{array}$ & $\begin{array}{l}\text { bersama } \\
\text { anak }\end{array}$ & $\begin{array}{l}\text { bersama } \\
\text { anak }\end{array}$ & $\begin{array}{l}\text { bersama } \\
\text { anak }\end{array}$ & $\begin{array}{l}\text { bersama } \\
\text { anak }\end{array}$ \\
\hline $\begin{array}{l}\text { Aktivitas } \\
\text { sehari-hari }\end{array}$ & $\begin{array}{l}\text { tidak } \\
\text { bekerja }\end{array}$ & $\begin{array}{l}\text { tidak } \\
\text { bekerja }\end{array}$ & Berdagang & $\begin{array}{l}\text { tidak } \\
\text { bekerja }\end{array}$ & $\begin{array}{l}\text { tidak } \\
\text { bekerja }\end{array}$ & berdagang \\
\hline $\begin{array}{l}\text { Suber } \\
\text { penghasilan }\end{array}$ & $\begin{array}{l}\text { pensiunan } \\
\text { suami }\end{array}$ & $\begin{array}{l}\text { pensiunan } \\
\text { suami }\end{array}$ & $\begin{array}{l}\text { hasil } \\
\text { usaha dan } \\
\text { pemberian } \\
\text { anak }\end{array}$ & $\begin{array}{l}\text { pensiunan } \\
\text { suami }\end{array}$ & $\begin{array}{l}\text { pemberian } \\
\text { anak }\end{array}$ & $\begin{array}{l}\text { hasil } \\
\text { usaha dan } \\
\text { pemberian } \\
\text { anak }\end{array}$ \\
\hline Jumlah anak & 4 & 7 & 5 & 5 & 3 & 2 \\
\hline Kondisi fisik & sehat & sehat & sehat & sehat & sehat & sehat \\
\hline
\end{tabular}

Pengumpulan data pada penelitian ini menggunakan metode wawancara dan observasi. Metode wawancara merupakan metode pengumpulan data yang utama dalam penelitian ini. Jenis wawancara yang digunakan adalah wawancara tidak terstruktur, artinya peneliti membuat panduan dalam melakukan wawancara. Selanjutnya, pertanyaan yang muncul akan berkembang secara alami. Observasi dalam penelitian ini merupakan metode pendukung. Hasil observasi digunakan sebagai data tambahan bagi peneliti dalam memahami dunia pengalaman subjek. Pada penelitian ini, observasi yang dilakukan adalah observasi langsung (tanpa menggunakan peralatan khusus) dan bersifat partisipatif, yaitu peneliti turut mengambil bagian dalam situasi nyata bersama subjek.Peneliti membuat catatan tertulis tentang apa yang didengar, dilihat, dialami, dan dipikirkan dalam rangka pengumpulan data dan refleksi terhadap data dalam penelitian kualitatif.

Wawancara terhadap keenam subjek penelitian dilakukan di kediaman masing-masing subjek yang bertempat tinggal di sekitar Kota Semarang. Semua subjek memiliki status sosial ekonomi pada tingkat menengah, yang berarti semua subjek tinggal di rumah yang layak, tercukupi kebutuhan pokoknya dan 
tidak mengalami kekurangan secara finansial. Secara fisik keenam subjek tampak sehat, aktif dan mandiri (tidak membutuhkan bantuan fisik dari orang lain). Semua subjek juga memiliki kemampuan komunikasi yang baik, mereka mampu menjawab pertanyaan dengan tepat dan menunjukkan pola bicara yang konsisten serta kongruen. Hal ini menunjukkan bahwa semua subjek dalam kondisi yang sehat secara mental.

Data yang telah diatur dan dibaca kembali oleh peneliti kemudian disaring dengan memilih hanya data yang penting dan berkaitan dengan penelitian saja. Data-data yang penting tersebut kemudian dipisahkan, dengan cara inilah peneliti melakukan proses horisonalisasi. Selanjutnya data yang penting dari ucapan subjek dapat diidentifikasi dengan bantuan transkrip wawancara, yang kemudian diberi cetak tebal, dicetak miring, atau digarisbawahi. Data tersebut kemudian ditulis di kolom tersendiri untuk memperjelas bahwa data itu penting. Tahap berikutnya adalah tugas peneliti untuk melakukan coding (kategorisasi data) dan menemukan makna psikologis dari data yang ditemukan.

Tahapan yang telah dilakukan menghasilkan 12 makna psikologis, meliputi: 1) Kekaguman terhadap pasangan hidup. 2) Perasaan kehilangan. 3) Kemandirian. 4) Strategi coping secara religius (religious coping strategies). 5) Dukungan sosial. 6) Keterlibatan sosial. 7) Penyesuaian diri autoplastis. 8) Kesepian emosional. 9) Penerimaan diri. 10) Keterikatan sosial. 11) Perasaan bahagia dan bersyukur. 12) Pandangan yang positif tentang kehidupan.

Dari hasil horisonalisasi di atas, peneliti menemukan 7 unit makna, yaitu: 1) Kedekatan dengan pasangan hidup. Unit makna ini terdiri dari kekaguman terhadap pasangan dan perasaan kehilangan saat kematian pasangan hidup. 2) Penerimaan diri. Unit makna ini terdiri dari penerimaan diri. 3) Rasa penerimaan terhadap lingkungan. Unit makna ini meliputi penyesuaian diri secara autoplastis. 4) Semangat bertahan hidup. Unit makna ini meliputi kemandirian dan strategi coping secara religius. 5) Kesepian. Unit makna ini terdiri dari kesepian emosional. 6) Interaksi sosial. Unit makna ini terdiri dari dukungan sosial, keterlibatan sosial, dan keterikatan sosial. 7) Kesejahteraan subjektif (subjective well being). Unit makna ini terdiri dari perasaan bahagia dan bersyukur, serta pandangan yang positif tentang kehidupan. 


\section{B. Pengalaman Kesepian pada Janda Lanjut Usia}

Dalam penelitian ini peneliti berhasil didapatkan oleh peneliti berjumlah 7 unit makna, yaitu kedekatan dengan pasangan hidup, penerimaan diri, rasa penerimaan terhadap lingkungan, semangat bertahan hidup, kesepian, interaksi sosial, dan kesejahteraan subjektif. Selanjutnya unit-unit makna tersebut akan dipaparkan dalam penjelasan yang disertai dengan kutipan hasil wawancara dengan subjek, seperti di bawah ini.

\section{Pertama, Kedekatan dengan Pasangan Hidup}

Kedekatan dengan pasangan hidup adalah perasaan yang menghubungkan kita dengan pasangan hidup, dan dapat dirasakan secara fisik maupun emosional (psikologis). Kedekatan memungkinkan seseorang untuk mengenal secara mendalam dan membentuk kekaguman akan sifat dan watak pasangan hidupnya, seperti yang disampaikan Subjek $1(\mathrm{Kr})$ berikut ini:

"Suami yang baik... suami yang selalu mengalah... kalau misalnya ada... kesulitan-kesulitan... kita selalu berunding, dan... suami saya selalu menghendaki [mengijinkan], misalnya pak, untuk biaya anak...ini harus dijual. Ya sudah ndak papa.. toh nanti juga Tuhan akan memberi kita rejeki lagi kalau anak-anak itu sudah bekerja. Dari dulu memang dia selalu mengalah... bapak itu termasuk suami yang baik, yang sempurna."

Subjek 2 (Ka) menunjukan rasa kagum pada sosok suaminya, menurut subjek suaminya sangat menyayangi anak-anak mereka bahkan jarang bersikap keras meskipun dia adalah seorang tentara. Hal tersebut muncul dalam pernyataan subjek sebagai berikut:

"Suami saya itu orangnya gak mentingin dirinya sendiri, apa-apa buat anak... sayang banget sama anaknya... "aku ini udah gak usah terlalu diopeni, aku ki udah gak butuh sangu werna werno, sing penting ki ngurusi anak aja itu udah besar-besar" gitu kata suami saya... Gak galak jarang memarahi anak istri padahal tentara... sampe anak saya itu gak boleh diberhentikan minum ASInya padahal sudah besar."

Subjek 3 (R) adalah sosok istri yang sangat menghargai kerja keras suami, merasa bangga mempunyai suami yang bertanggung jawab terhadap anak dan istrinya. Hal ini terlihat dari antusiasme subjek saat menceritakan bagaimana sosok suami dimatanya, subjek menyatakan bahwa: 
"Mbah kakung ki baik orangnya.. Kerja keras berangkat pulang berangkat pulang... gak kenal capek cari nafkah untuk anak istri macul di sawah di kebon nandur sayuran nandur puhung, nandur padi.."

Pasangan hidup menurut subjek 4 (S) merupakan sosok orang yang baik, sayang keluarga dan juga perhatian. Hal tersebut yang membuat subjek mengerti bagaimana karakter pasangannya yang menimbulkan kekaguman. Kekaguman itu ditunjukkan dengan penyampaian subjek tentang sosok pasangan hidupnya yaitu terdapat penekanan pada kata-kata tertentu seperti berikut:

"Eyang kakung baik sangat baikkk, sayang .... sayanggg keluarga.... perhatian....”

Subjek 5 (Z) menaruh kekaguman yang mendalam kepada suaminya, karena suaminya adalah sosok yang sangat perhatian dan menyayangi keluarga. Hal ini terlihat dari ekspresi subjek yang berkaca-kaca dan ungkapan subjek:

"Kalau dia punya uang, ngajak pergi saya kemana... kemauan saya dituruti... Beli macam-macam buat anak-anak. Semuanya baik... semuanya tuh buat keluarga. Bapake orangnya sering memperhatikan semuanya gitu ya dan gak pernah macam-macam... kalau pulang dari luar kota biasanya dia beli-beli baju, jajanan, kosmetik macam-macam."

Hubungan dengan pasangan hidup tak akan berjalan baik jika tidak terdapat faktor kedekatan antar personal. Kedekatan ini menjadi kunci dalam memahami pasangan dan menjadi kekaguman terhadap watak dan sifat pasangan hidupnya, seperti yang disampaikan subjek 6 (Ku)sebagai berikut,

“Bapak merupakan sosok ayah sekaligus suami yang baik, bapak itu perhatian. Kalau libur sekolah bapak rela ambil cuti buat jalan-jalan ke luar kota bersama keluarganya."

Kedekatan yang terjalin dalam sebuah hubungan setelah sekian lama, akan menimbulkan dampak kehilangan yang besar jika pasangan hidup meninggal dunia. Perasaan kehilangan tersebut juga dirasakan oleh subjek 1 (Kr) sebagaimana disampaikan dalam pernyataan berikut ini:

"Rasanya juga sedih sekali... bingung... seakan-akan suami saya masih [hidup]... jadi ndak tau-tau tu saya dah bikin minum, saya ingat, aduh, suami saya sudah meninggal... kok kenapa tergesa-gesa abis shalat saya bikin minum ternyata suami saya sudah tidak ada.... 40-hari [setelah meninggal] masih kalau malam ya tidur tidak bisa nyenyak, masih ingat, terus saya berpikir, aduh... kalau 
suami saya masih [hidup] pasti saya begini, kalau suami masih [hidup] pasti saya dapat undangan teman saya yang baik pasti berdua pergi."

Ditinggal oleh pasangan hidup dapat memunculkan berbagai reaksi fisik maupun psikis. Subjek 2 (Ka) menunjukan adanya perasaan kehilangan dan kebingungan, mengingat saat itu subjek harus mengasuh 7 orang anak.

"Rame konco-konco militere suami dateng upacara bawa senjata waktu mau di makamkan... La gimana saya ditinggali anak 7 kok apa gak bingung kalo Mbak jadi saya... Aku mikiri makan dan sekolah anak-anak. Anakku sekolah di STM..."

Seseorang yang kehilangan sosok yang penting bagi dirinya, paling berpengaruh dalam hidupnya, serta paling dicintainya untuk selama-lamanya tentu merasakan sedih dan kehilangan. Begitupun dengan subjek 3 (R), subjek merasakan sedih dan kehilangan saat suami yang dicintainya meninggal dunia.

"Namanya ditinggal ya pasti sedih, sehari dua hari itu ya kerasa banget. pertama ditinggal ya sedih soalnya orangnya sudah bakal nggak ada lagi apalagi kita dulu kan seringnya cuma tinggal berdua, anak-anak tinggal di atas.."

Kedekatan subjek dengan sosok pasanganya menimbulkan rasa kehilangan ketika belahan jiwa meninggal dunia. Tetapi hal tersebut dapat diatasi dengan baik oleh subjek 4 (S), karena menyadari dan menyerahkan semuanya kepada Tuhan Yang Maha Esa.

"Kalau dibilang sedih ya sedih Mbak... tapi bagaimana lagi Mbak harus ikhlas karna yang mundhut Yang Kuasa aku ikhas Mbak walau bagaimana lagi.... karena semua itu yang ngatur Allah Mbak... kita tinggal terima.... memang Allah menghendaki seperti ini."

Berbeda dengan subjek 4 (S) yang mampu menerima kepergian suami, subjek 5 (Z) masih merasakan kehilangan yang mendalam atas kepergian suaminya. Hal ini terlihat dari ungkapan subjek:

"Seperti kehilangan semuanya... Ditinggal tu kaget... Pokoknya lainlah yang dirasakan... merasa kehilangan... jika bapak masih hidup, saya ingin lebih perhatian dan tidak memarahi bapak kalau bapak bandel tetap merokok ngumpet-ngumpet."

Apapun yang sudah dimiliki sejak lama dan telah terjiwai, maka serasa ada yang hilang dan tidak lengkap jika yang terkasih meninggalkannya, seperti halnya yang dirasakan oleh subjek $6(\mathrm{Ku})$ berikut:

"Ya kalau sedih ya sedih karena dimanapun kalau ditinggal selamanya ya..." 
Kedekatan dalam sebuah hubungan dengan demikian, tidak hanya dapat dilihat dari sejauh mana keakraban dan kualitas hubungan antara seseorang dengan pasangan hidupnya di satu tempat saat bersamaan. Sejauh mana kedekatan seseorang juga dapat dilihat dari dampak yang ditimbulkan jika keduanya harus berpisah. Kedekatan secara fisik belum tentu menghasilkan dampak secara psikis dalam melahirkan rasa cinta dan kasih sayang, meskipun ada kemungkinan ke arah itu jika mengingat pepatah Jawa, witing tresna jalaran saka kulina (ada cinta karena terbiasa bersama). Namun, dalam hubungan percintaan, terutama antar suami dan istri, keduanya terjadi. Kedekatan dalam hubungan suami dan istri terjadi secara fisik dan emosional (psikis). Suami dan istri tinggal di bawah satu atap, berdekatan secara fisik, dan memiliki kedekatan emosional yang diperkuat oleh perasaan cinta antara mereka. Kedekatan ini memungkinkan keduanya mengenal pasangan mereka, karena seringnya berinteraksi akan memunculkan kekaguman atau kebencian tergantung banyaknya sifat atau watak yang muncul apakah dinilai baik atau buruk. Selanjutnya, akan berdampak apabila salah satu pasangan meninggal dunia, muncul dampak yang berganda, kehilangan secara fisik dan emosional. Rasa kehilangan dapat diterjemahkan lewat kesedihan, perasaan hampa, atau kesepian.

\section{Kedua, Penerimaan Diri}

Penerimaan diri (self acceptance) adalah sejauh mana seseorang merasa puas dengan dirinya sendiri dan mengetahui batasan-batasan dalam dirinya. Penerimaan diri kemudian membentuk sifat, atau sekedar pencerahan (insight) setelah melalui proses pemahaman tertentu. Proses inilah yang terjadi pada diri subjek 1, seperti pernyataannya berikut ini:

“[Kesepian] berdampak baik juga. Karena biasa kok... hanya nglangut²3 [kesedihan terkait perasaan sepi]-nya itu kadang-kadang, wah saya kok begini, terus saya ingat bahwa itu Tuhan yang memberi, semua itu takdir, sudah ditulis oleh Allah, jadi tidak mengalami kesepian yang sungguh, dan saya tidak merasa buruk. Kesepian itu ya biasa, setiap orang janda pasti mengalami. Saya berusaha menganggap itu baik, ndak buruk."

${ }^{23}$ Dalam bahasa Jawa, nglangut: 1) katon adoh bangêt [tampak jauh sekali]; 2) sêdhih bangêt [kesedihan yang mendalam]; baca: Poerwadarminta, "Bausastra Jawa, Poerwadarminta, 1939, \#75 (Bagian 18: NG) - Sastra Jawa," Bausastra Jawa, 1939, https://www.sastra.org/bahasa-danbudaya/kamus-dan-leksikon/798-bausastra-jawa-poerwadarminta-1939-75-bagian-18-ng. 
Subjek 2 merasakan dampak positif dari berserah diri dan berdoa sehingga membantunya melawan pikiran tentang kesepian yang dialaminya. Subjek menyadari penurunan kondisi fisiknya sehingga ia lebih mendekatkan diri kepada Allah dan bersyukur karena diberi usia yang panjang.

"Lha piye bapak sudah nggak ada ya sudah didoakan saja... teman-teman saya juga sama itu udah pada nggak ada suaminya malah sebagian teman saya sudah ada yang meninggal... jadi ya udah saya paling banyakin doa aja.." dan saya mikir anak-anak sudah pada berkeluarga... cucu-cucu sudah banyak... jadi udah paling saya tinggal nganggur, makan, tidur, ngaji, mainan sama cucu.."

Hampir sama dengan subjek 2, subjek 3 sadar dan menerima suratan ilahi sehingga membuat subjek merasa lebih ikhlas dalam menjalani hidup dan menerima kesendiriannya. Berserah diri terhadap sang pencipta membawa dampak positif pada diri subjek. Seperti ucapan subjek berikut ini:

"Ya gimana lagi ya, tapi ya mau gimana... Ya sudah gak gimana-gimana namanya sudah diambil... " dan "Kalo lagi teringat saya malem Jumat doain Mbah Kakung yasinan ngaji... Nyuwun sama Gusti Allah pengampunan... kadang ziarah ke makam mbah kakung."

Subjek 4 menunjukkan penerimaan diri yang cukup baik. Karena subjek sangat religius sehingga subjek selalu berpikir positif dan selalu ingat kepada Tuhan Yang Mahaesa. Jadi ketika sudah mengkomunikasikan masalah dengan Tuhan, ia merasa seolah-olah dipermudah semuanya seperti yang diungkapkan subjek sebagai berikut:

"Saya langsung ingat.... ya Allah maaf ya Allah saya mung gitu.... kalau nggak gitu malah mikir terus.... kalau sudah komunikasi dengan Allah seolah-olah tenang terus...."

Subjek 5 mampu menerima kepergian suami dengan menjalankan aktivitas positif. Hal ini seperti yang diungkapkan subjek:

"Beberapa bulan saya sempat merasa kehilangan, setelah itu saya bisa berpikir... semuanya kembali ke sana... walau dibetuli ya tetep ndak bisa pulang kan... ya udah gitu."

Semuanya adalah kehendak dari Allah dan merupakan takdir yang harus diterima dan disyukuri. Apalagi dalam konsepsi Jawa mengenal filosofi nerima ing pandum. Hal ini tergambar dalam pernyataan subjek 6 yaitu: 
"[Jika bapak masih ada] jika dapat diulang kembali ya kayak rumah tangga biasa ya kita patuh pada suami... ndak ada nuntut ini nuntut itu [menerima]... [bapak sudah meninggal] ya pasrahkan saja itu sudah takdirnya Allah... jadi kita ikhlas."

Telah jelas bahwa penerimaan diri memberikan manfaat bagi seseorang untuk dapat menerima perubahan kondisi yang dialami, terutama berkaitan dengan usia yang menghasilkan beberapa perubahan yang tidak dapat dihindari. Penerimaan diri dapat mewujudkan konsep diri dan harga diri yang sehat karena seseorang mampu menganalisa dirinya, menjadi "raja" atas dirinya sendiri. Selanjutnya, hal ini akan menghasilkan rasa puas dan kebahagiaan dalam diri seseorang.

\section{Ketiga, Rasa Penerimaan terhadap Lingkungan}

Rasa penerimaan terhadap lingkungan berarti menyadari bahwa lingkungan tidak selamanya mampu memenuhi keinginan, dan tidak selalu berjalan sesuai yang diharapkan. Subjek 1 mampu menerima keadaan lingkungan, dan berusaha menyesuaikan diri secara autoplastis, di mana diri bertindak sebagai komponen yang aktif berubah untuk dapat mengikuti kemauan yang diarahkan oleh kekuatan dari luar (lingkungan eksternal). Hal ini ditunjukkan oleh pernyataan subjek 1 di bawah ini,

“[Awal-awal menjanda] Itu memang saya merasa sepi. Tapi kebetulan tetangga... baik sekali, seringkali main... selalu menghibur saya. Jadi saya rasa ndak begitu...merasa kesepian. Cuma nglangut-nya itu kalau malam.... sendirian.... Terus saya cepet-cepet ambil air wudlu... shalat tahajud.... tidak merasa kesepian, sungguh... karena... sudah lama.... ditinggal suami sakit sampai 2 tahun.... sudah terbiasa."

Kehilangan pasangan hidup membuat seseorang menemui situasi yang berbeda, mengharuskannya melakukan berbagai penyesuaian diri. Salah satu hal yang mungkin dialami individu yang baru kehilangan pasangannya adalah merasa kesepian. Namun dalam hal ini subjek 2 mengaku lingkungannya membuat dirinya tidak pernah merasa kesepian. Hal itu dinyatakannya dalam kalimat berikut:

"Gak pernah kesepian Mbak saya, jarang sepi soale... di sini kumpul anak-anak cucu-cucu tetangga-tetangga juga rame... Di sini tetangga-tetangga gak membeda-bedakan... gak ada yang pinter gak ada yang bodo sama semua kaya yo ayok miskin yo ayok... Lha wong dulu di sini ini masih desa kok.." 
Subjek 3 adalah seorang yang mampu menyesuaikan diri dalam kesepiannya. Hilangnya kesepian subjek 3 adalah karena kesibukannya, keberadaan anak cucunya nya, dan keakraban dengan tetangganya, sehingga merasa terbiasa. Seperti yang ia ceritakan,

"Ini makanya saya buka warung kecil ini buat supaya ada kegiatan buat obat ngantuk... kalo ngaji saya ngaji ... dulu pas waktu di pasar Johar itu rame temenne... sekarang sudah 4 tahun saya gak jualan di pasar lagi.. Anak-anak kalo habis bayaran main ke sini ngasih uang padahal saya gak minta tapi dikasih."

Penyesuaian diri subjek 4 sangat bagus meskipun latar belakang lingkungan yang berbeda, meskipun awalnya subjek merasa susah tetapi subjek bisa mengatasinya dengan baik. Subjek merupakan orang yang tidak bisa diam harus beraktivitas dan juga berinteraksi dengan lingkungannya. Hal tersebut seperti ungkapan subjek:

“.... sepi Mbak.... soalnya adaptasi susah beda.... dulu di Pekalongan sekarang di Semarang .... namanya juga orang kota Mbak .... susah tidak ada yang peduli .... untung ada ibuknya Bagus ini (nama tetangga) baik banget.... suka ga bolehin saya ngerjain hal-hal yang berat.... "eyang jangan" baik banget Mbak.... sudah kayak keluarganya sendiri.... memasak apapun selalu sampai ke saya Mbak...."

Berbeda dengan subjek 4, setelah suami subjek meninggal, subjek 5 sempat terpuruk beberapa bulan. Namun setelah itu, subjek kembali menjalankan kehidupan bersama anak dan cucunya. Hal ini terlihat dari ungkapan subjek:

"Sempat beberapa bulan ya, saya merasa kehilangan... setelah itu saya bisa berpikir... Seringan tinggal kaleh ibune Nia (nama cucunya)."

Setiap orang jika dihadapkan pada situasi yang baru tentunya akan melakukan penyesuain diri sebagai wujud adaptasi. Respon alamiah ini merupakan bentuk kemampuan menyikapi diri. Gambaran ini terlihat pada subjek 6 dalam melakukan penyesuaian diri pasca suami meninggal:

"[Apakah masih merindukan suami] Andaikata ngimpi bapak... ya kayak kehidupan biasa sedang ini sedang itu... [bahkan ngerasa] kadang-kadang kok udah mati kok kelihatan... [padahal sudah meninggal] kok hidup lagi.. [tak jarang] kadang-kadang sadar kalau sudah meninggal.... [setelah itu] mpun [sudah] puluhan tahun ya wis [sudah] diikhlasake biar mendapat tempat yang 
baik... [kemudian] mendoakan selalu.... Ibu juga nggak pernah sedih anaknya selalu kumpul pada menghibur."

Penyesuaian diri secara autoplastis, dengan demikian menunjukkan rasa penerimaan terhadap lingkungan. Lingkungan berperan sebagai pemberi rangsangan, juga sebagai sumber konflik dan permasalahan. Seseorang dapat menyesuaikan diri secara autoplastis atau alloplastis. Penyesuaian alloplastis berarti individu berusaha memberikan perlawanan terhadap masalah. Perlawanan terhadap lingkungan ini dilakukan untuk memudahkan individu mengatasi masalah, dengan menjauhkan atau meminimalkan pengaruh rangsangan yang berasal dari lingkungan, misalnya membuang barang-barang kenangan agar tidak lagi mengingat pasangan hidup yang telah meninggal. Penerimaan terhadap lingkungan, muncul dalam penyesuaian diri autoplastis, di mana individu tidak berusaha mengeluarkan upaya perlawanan melainkan berusaha mengatasi masalah dengan berfokus pada upaya pribadi untuk mengatasi sendiri dampak dari masalah yang dialami, misalnya dengan berserah diri kepada Tuhan.

\section{Keempat, Semangat Bertahan Hidup}

Semangat bertahan hidup (survival) dapat dilihat dari kemampuan individu untuk bertahan dari tekanan lingkungan, bangkit dari keterpurukan, dan selalu berusaha mengatasi masalah. Semangat ini ditunjukkan subjek 1 ketika menyampaikan keinginannya untuk mandiri sebagai berikut:

"[Setelah kematian suami] Itu saya bisa menyesuaikan tu setelah 100 hari, sudah tidak terlalu ingat, bisa menyesuaikan, oh iya, saya sekarang sudah janda, dan saya hidup sendiri, harus bisa hidup sendiri, tidak tergantung dengan suami atau anak-anak saya yang [tinggalnya] jauh, jadi saya tu selalu berdoa supaya diberi kesehatan, dan kalau misalnya dipundhut [meninggal] saya berdoa semoga tidak diberi penyakit yang macem-macem."

Meninggalnya suami juga tidak membuat subjek berlarut-larut dalam kesedihan, anak-anak menjadi motivasi subjek dalam melanjutkan hidupnya, subjek mampu menerima kesendirian, tetap bersemangat dalam hidup dan membesarkan anak dengan baik. Seperti yang diungkapkan oleh subjek:

[\#2] "Tapi aku sehat wae rak sedih nangis teriak-teriak. Aku tak-coba [mencoba] tegar mawon... Lha piye wong udah meninggal kan gak baik ditangisi. Aku jadi ya gak gimana-gimana coba tenang aja, kasihan anak.. Dulu saya 
hutang 5 juta untuk beli sawah dua tempat, bayarnya pakai hasil sawah sama pensiunan suami... Tak-buat makan dan sekolah anak-anak alhamdulillah cukup.. Pas anak saya menikah sawahnya saya jual untuk beli rumah ini dan sekarang saya tinggal di sini.."

[\#3] "Aku ngurusi ngentaske anak menikah dari hasil jualan di pasar sama sawah... Mbah Kakung sudah 10 tahun meninggal anak-anak sekarang sudah menikah semua jadi sudah lega..."

[\#5] "Karena anak-anak sudah berkerja, jadi tidak sampai rekoso meskipun bapak tidak pensiun, tapi tetap masih bisa ngurus anak-anak".

Demikian pula dengan subjek 4 yang tidak sepenuhnya menggantungkan hidup kepada anaknya. Subjek merasa sehat secara fisik sehingga aktif memenuhi kebutuhan hidupnya sendiri. Seperti yang diceritakan oleh subjek:

“... sekarang sudah sendiri Mbak... dulu jauh sama anak.... harus apa-apa sendiri tidak bisa bergantung lain.... apalagi di lingkungan yang seperti ini Mbak , hanya bisa pasrahkan semua ke Allah karena semua sudah diatur oleh Allah.... minta pertolongan kepada Allah."

Semangat untuk bertahan hidup selain ditunjukkan melalu kemandirian, subjek juga menunjukkanusaha mengatasi perasaan kesepian atau kebosanan saat sedang sendiri dengan pendekatan religius (religious coping strategies), seperti disampaikan oleh subjek1 berikut ini,

"Kalau [sedang] sendiri ya nglangut ... terus saya cepet-cepet baca Qur'an... cepat-cepat ambil air wudhu, kita sholat, kita baca Alquran... [akhirnya] semua kesedihan saya itu bisa hilang."

Sama halnya ketika subjek 4mengalami kesepian, hal yang segera dilakukan subjek yaitu berusaha mengingat Allah dengan berdzikir kepada-Nya karena tidak ada lagi pelarian yang paling indah selain kepada Tuhan. Hal tersebut diungkapkan subjek seperti berikut:

“.... iya itu.... saya kalau sepi kok saya langsung dzikir... dzikir.... banyak berharap Allah memberi perlindungan .... kepada kita .... kalau kita sedih-sedih kok malah gimana gitu Mbak .... karna tidak ada pertolongan selain Allah"

Subjek 2 dan 5 mengatasi kesendirian dan kesepiannya dengan cara menyibukkan diri dengan kegiatan yang produktif dan beribadah. Hal ini terlihat dari ungkapan subjek sebagai berikut: 
[\#2] "Momong anak Mbak... ke sawah nengokin sawah... awur tonggo... tadinya dulu banyak pengajian sekarang kadang saya gak berangkat jalannya udah gak kuat... paling kala Subuh Maghrib sama Isya saya ke masjid walaupun jama'ahe cuma satu dua."

[\#5] "saya terus jualan pulsa... Saya ikut pengajian yang ada di sekitar rumah... kepikiran bapak, saya berdoa...kalau malam saya bisa bangun dan shalat tahajud."

Dengan demikian, dapat disimpulkan bahwa strategi yang digunakan untuk mengatasi perasan negatif akibat kesepian melalui kegiatan religius (religious coping strategies), dan kemandirian dapat menunjukkan sejauh mana seseorang mampu bertahan hidup, karena kebanyakan orang mendapat tantangan dari lingkungan untuk menguji bagaimana kemampuan seseorang dalam mengatasinya. Seseorang yang mampu beradaptasi dengan lingkungan, mengatasi masalah, dan mampu bersikap mandiri, lepas dari ketergantunngan dengan orang lain berarti memiliki daya juang yang tinggi untuk terus bertahan hidup (survive). Pada diri seorang lansia, semangat ini sangatlah diperlukan mengingat masa ini memerlukan sejumlah penyesuaian yang cukup sulit dan sangat ditentukan oleh disposisi kepribadian seseorang dan dukungan dari lingkungan. Salah satu isu yang seringkali mendatangkan masalah adalah ketergantungan (dependency), di mana seorang lansia acapkali merasakan dilema saat dirinya masih merasa kuat, namun di sisi lain dirinya mengalami kelemahan fisik akibat rentanya usia. Permasalahan lainnya adalah kesepian, ketika di usia tua biasanya seseorang harus hidup tanpa pasangan dan jauh dari anak-anak yang telah berkeluarga. Selanjutnya keberhasilan seseorang dalam mengatasi masalah ini akan tergantung dari semangatnya untuk bertahan, disertai dukungan sosial yang bersifat memberi kesempatan dan rasa aman.

\section{Kelima, Kesepian}

Kesepian adalah kegelisahan yang dirasakan secara subjektif pada saat seseorang merasa kehilangan ciri-ciri penting dalam hubungan sosialnya. Secara umum, kesepian dibedakan menjadi 2, yaitu kesepian sosial dan emosional. Kesepian sosial terjadi apabila seseorang merasa tidak memiliki keterlibatan sosial, misalnya tidak memiliki teman untuk mengobrol. Kesepian 
emosional dapat melanda seseorang ketika kehilangan pasangan hidup, seperti yang ditemukan dalam pernyataan subjek berikut ini:

[\#1] "[Hal yang menimbulkan kesepian] ...ya malam, saya ingat suami saya, saya ingat waktu dulu, dan saya ndak menyangka... Terus seringkali susah... terus saya hilangkan... tidak hanya saya yang ditinggal suami, semua... janda... pernah mengalami... Terus hilang.... kesepian saya."

[\#2] Kadang tu inget pas ditinggal pergi tugas, saya nyanyi 'begini rasanya di tinggal kekasih' gitu Mbak..."

[\#3] "Kalo nganggur gak ngapa-ngapin kadang teringat Mbah Kakung... kalo Ramadhan sama hari Lebaran kadang kerasa..."

[\#4] “.... waktu merasa kesepian yaitu waktu ga ada kegiatan.... ga ada pengajian.... jadi sok-sok nglangut kalau ada pengajian atau ngerjain suatu langsung ilang kesepiannya."

[\#5] "(Rasanya sepi) pas liat TV, biasanya bapak e mesti di sebelah duduk bareng-bareng... mau pergi kemana, ndak ada yang ngantar...kalau pulang dari luar kota biasanya dia beli-beli baju, jajanan, kosmetik macam-macam... sekarang dia pergi ndak ada apa-apa. Bapak datang di mimpi dengan pakaian kesukaannya dan rambut klimis serta wajah tersenyum berada di balik sungai, melambaikan tangan... bilang kalau aku disuruh samperin bapak."

Dapat dilihat, bahwa ketiadaan figur yang intim dapat menimbulkan rasa sepi, karena seseorang merasa tidak memiliki tempat untuk bergantung. Terlebih lagi di masa tua, ketika seseorang merasa sangat membutuhkan dukungan dan kasih sayang terutama dari pasangan yang telah hidup bersama sekian lama. Kesepian yang dialami lansia berkaitan dengan ketergantungan, karena di masa tua seseorang sangat membutuhkan respon emosional dari keluarga. Keadaan yang semakin menjauhkan lansia dari anak-anaknya yang telah berkeluarga, akan semakin terasa jika pasangan hidup juga meninggalkannya. Usia lansia memang rawan mengalami kesepian, karena pada umumnya lansia lebih memilih hidup sendiri ketimbang hidup bersama di dalam rumah tangga anaknya. Selanjutnya hal ini ditentukan oleh dukungan emosional dari keluarga untuk lebih memperhatikan lansia dan menjauhkannya dari dampak buruk kesepian.

\section{Keenam, Interaksi Sosial}


Interaksi sosial memiliki makna proses hubungan antar perorangan yang berlanjut terus antara individu atau lebih. Interaksi sosial dapat terwujud melalui dukungan sosial antar individu, seperti yang dinyatakan subjek berikut ini:

[\#1] “[Saya] Pernah tinggal sendiri selama 2 tahun....Tapi... setiap satu minggu sekali anak saya dan keponakan saya pasti datang untuk menengok.... tidak merasa kesepian betul... bisa saya telepon.... [Saat tinggal sendiri]... kesulitan [dalam aktivitas sehari-hari] sehari-hari tidak ada.."

[\#2] Gak pernah sendiri saya Mbak soale anak-anak kan ikut saya semua dulu sampe sekarang. Akeh anak cucu itu malah cucuku udah ada yang punya anak 2 Anak-anak dan mantu sering kirim doa ngajiin almarhum suami saya. Anakku 7 tinggal di Semarang semua, sering sedekah di masjid buat almarhum..."

[\#3] "Jarang sendiri si Mbak. Semenjak Mbah Kakung meninggal anak saya yang ini tinggal di sini nemenin saya.... sekarang banyak cucu-cucu... anak-anak juga ngurusi aku kok Mbak setiap gajian saya dikasih uang..."

[\#4] "Sebelum saya tinggal sama anak saya yang terakhir ini saya tinggal sendiri Mbak kurang lebih 15 tahunan.... waktu itu saya tinggal di Pekalongan dan jauh sama anak-anak saya semua akhirnya saya yang ngalah untuk mendekat ke anak saya.... kemudian jual rumah yang di Pekalongan.... kemudian saya belikan rumah ini.... soalnya kalau anak nengok orang tua hanya satu tahun sekali kok saya merasa gimana gitu Mbak... Nah saya tinggal di sini sudah 20 tahunan.... dan 15 tahun hidup sendiri Mbak.... saya nyuruh anak saya untuk pulang kok tidak mau.... katanya kalau di Semarang susah cari kerja makanya tidak mau pulang Mbak .... untung ada ibunya Bagus (tetangga) yang baik sekali kalau masak apa-apa pasti sampai ke eyang dan juga baik sekali.... perhatian Mbak sama saya.... sudah seperti keluarga sendiri.."

[\#6] "Di rumah ibu tinggal sama Mbak Dewi... Ketika anak-anak pergi ibu nggak kesepian. Tetangga ibu banyak... Tetangga saya, juga anak saya...[pula] anak-anak juga eman [peduli]".

Interaksi sosial juga terlihat dari sejauh mana keterlibatan seseorang secara sosial. Keterlibatan ini dapat diwujudkan melalui organisasi dan kegiatan kemasyarakatan, seperti dalam pernyataan subjek berikut,

[\#1] "... kegiatan saya di organisasi itu banyak sekali, terus anak saya yang nomor satu itu mengatakan...'mbok dikurangi.... jadi saya minta ijin dengan pak RT dan pak RW, sekarang kegiatan... ndak begitu padat, hanya... tetap harus jadi... istri Worokawuri.... tetap pengurus PEPABRI....[sebagai] Sekretaris... 
Harus lapor ke KODIM... [jadi] pengurus pensiun jandanya.... Pengajian yang malam hari... seminggu sekali.... [saya juga] jadi pengurus di RT 01, jadi pengurus pengajian.....[dan] karena tempat tinggal saya itu semua orang pensiunan... [semua warga] sudah tua... [saya] ditunjuk sebagai... pos lansia... jadi pengurusnya.... [kegiatan] Senam, satu minggu sekali, hari minggu jam 6, senam lansia."

[\#2] "Pagi Subuh itu saya kemasjid jamaah sambil buat olahraga... kadang kalo yang dekat-dekat saya ikut ngaji... ini paling ya gini-gini aja Mbak kalo sore duduk-duduk di depan rumah ngobrol sama tetangga-tetangga... cerita-cerita zaman dulu waktu masih muda..."

[\#3] "Lha saiki pengajian setiap malem Jemuah Yasinan, Tahlilan Berjanjen.. Dulu saya ikut satu minggu dua kali tapi sekarang udah hilang separuh jama'ahe gara-gara digusur jalan tol jadi sekarang dijadikan satu kumpulanya seminggu sekali..."

[\#4] “Kegiatan Eyang.... ke mana-mana di masjid, saya gini ya Mbak.... waktu 6 tahun lalu kan saya umroh waktu di masjid itu, ketika melihat orang datang kok bawa al-Quran.... tapi saya tidak tahu dimana tempat mengambilnya.... karana mau bilang tidak mudeng bahasanya.... akhirnya saya ngikutin orang itu di mana ngambil al-Quran.... nah dari situ Alhamdulillah Mbak saya kalau mau baca al-Quran pasti di masjid habis magrib sampai isya'.... sampai-sampai ibuknya ini bilang Eyang.... tidak capek engga papa... habis Magrib itu kan sudah sepi.... saya ngambil al-Quran belajar.... ya kalau setumpul-tumpulnya pisau kalau diasah setiap hari ya pasti bisa.... jadi kalau ada pengajian RW kan setiap Jumat pada nyimak saya juga ikut sedikit sedikit."

[\#5] "Saya ikut pengajian yang ada disekitar rumah"

[\#6] "Ibu warungan [jualan] kayak gini, jadi tetep ada kegiatan... tutupnya sampai jam sembilan malem...[setelah itu] kalau ada yang beli... [lalu] ngobrolngobrol... sama tetangga...[termasuk kegiatan observasi dan wawancara ini] jadi seneng kalau diwawancara..."

Kualitas hubungan dapat dilihat dari keterikatan sosial, yaitu sejauh mana seseorang memiliki ikatan dengan orang yang berhubungan dengannya di dalam lingkup sosial. Hal ini pun disampaikan subjek dalam pernyataan berikut ini,

[\#1] "Ya ndak kesepian karena rata-rata [warga sekitar]... pensiunnya sama... kegiatan ya sama, kesenangan... bersama.... Jadi kita merasa puas, merasa senang, senasib seperjuangan.... perumahan [yang ditinggali]... khusus ABRI.... [antar warga] sudah [merasa] senasib seperjuangan." 
[\#6] "Ndak sih Mbak...., anak-anak juga menghibur..., tetangga di rumah banyak... Jadi ndak pernah ngerasa sedih juga kesepian. Pelanggan-pelanggan podo moro [pada datang] buat beli telur puyuh... [terus] ngobrol-ngobrol.... [selain itu] anak pada kumpul... [jadi] seneng".

[\#2] "Seringe saya nyayi Mbak... nembang. Kumpul duduk di depan rumah ngobrol sama tetangga... kadang beli bakso yang sering lewat... Di sini juga kan anak saya buka bengkel jadi saya kadang ngombrol sama orang yang dandani motornya..."

[\#3]“Kulakan barang jualan sedikit-sedikit... main ke rumah anak kan gak terlalu jauh nengokincucu.. jadi gak kesepian wong ada anak ada cucu-cucu bisa buat hiburan.."

[\#4] “.... biasa saya bersih-bersih apa gitu Mbak kemudian kalau ada hajatan.... nah nasinya biasanya dikasihkan disaya nanti saya jemur kemudian saya jual.... nantinya uang saya infaqkan ke masjid Mbak, ya itu sedekah mereka.... Kalau ga gitu ya dedet-dedet suket (mencabuti rumput) depan rumah.... kemudian di tanemi sesuatu Mbak .... nanti hasilnya juga kita nikmati bersama"

Maka dapat disimpulkan bahwa dukungan, keterlibatan, dan keterikatan sosial merupakan hal yang berkaitan dengan interaksi sosial. Dukungan sosial merupakan hasil dari interaksi sosial yang saling menguntungkan, di mana kedua belah pihak merasa saling memberi dan menerima dukungan secara fisik maupun emosional. Dukungan sosial dapat menghilangkan kesepian yang dialami seseorang, karena hal ini merupakan salah satu ciri penting dalam interaksi sosial yang tidak dirasakan orang yang kesepian. Orang yang mendapat dukungan sosial akan merasa dihargai, merasa memiliki arti sehingga tetap mampu menjalankan peran sosialnya dan terbebas dari siksaan kesepian. Interaksi sosial, mutlak membutuhkan keterlibatan antar individu di dalamnya. Maka dapat dikatakan bahwa keterlibatan sosial adalah derajat interaksi sosial, yang dapat dinyatakan dalam tingkatan yang rendah hingga yang paling tinggi. Keterlibatan juga berkaitan dengan bentuk interaksi sosial, sehingga dapat terwujud secara formal atau nonformal, fisik atau emosional. Keterlibatan sosial dapat bermula dari sekedar ikut menjadi pendengar dalam suatu obrolan, hingga terlibat dalam suatu hubungan organisasional yang formal dan intens. Semakin lama, interaksi sosial akan membentuk sebuah ikatan antar individu yang terlibat di dalamnya. Berkaitan dengan konsep keterlibatan yang telah saya jelaskan sebelumnya, keterikatan juga bervariasi menurut bentuk 
dan tingkatannya. Hal yang membedakan keduanya adalah bahwa keterikatan sosial menunjukkan adanya persamaan tujuan dan kebutuhan antara individu yang terlibat di dalamnya. Dapat dikatakan bahwa keterlibatan dalam interaksi sosial yang terus menerus akan memperjelas tujuan yang akan dicapai, sehingga individu yang terlibat merasa memiliki kebutuhan yang sama dan saling terikat satu sama lain.

\section{Ketujuh, Kesejahteraan Subjektif}

Kesejahteraan subjektif (subjective well being) adalah kesejahteraan psikologis secara umum, atau penilaian global seseorang mengenai kepuasan hidup. Perasaan sejahtera atau bahagia adalah komponen utama kualitas hidup positif seseorang. Perasaan bahagia dan bersyukur serta pandangan positif tentang kehidupan muncul dalam ucapan subjek sebagai berikut:

[\#1] "[Saat ini]... sudah merasa senang, merasa bahagia meskipun saya hidup sendiri... Anak-anak pada mencintai saya.... Merasa sudah puas dan senang, anak saya selalu... memikirkan.... melindungi saya. Jadi saya merasa bahagia, merasa puas Tuhan memberi kehidupan begini...."

[\#2] "Alhamdulillah saya dikasih panjang umur sampe sekarang..., dikasih kesehatan kemurahan rizki oleh Allah... Anak saya saya rumat semua sampe lululsan STM, semua yang cewek SMA. Alhamdulillah anak-anak pada sae (baik) pada inget sama orangtua... nggak pernah lupa doain almarhum bapaknya... Wes aku rak pengen opo opo lagi udah sepuh kok mau apa lagi."

[\#3] "Karang sekarang ikut anak, udah tua udah ya kaya gini aja ngisi kesibukan... alhamdulillah anak sudah mentas semua, sudah misah semua, cucu sudah banyak... jadi ya tinggal ngibadah karo istirahat wes tua mau apa lagi."

[\#4] “... ya hanya menyerahkan kepada Allah sajalah.... pasrah.... Namanya sudah sepuh..., kegiatan saya ya.... bukan kegitan anak muda.... Sudah saya ngepen-kan (fokus) kegiatan di masjid, pengajian dan juga ngaji di masjid dan banyak belajar al-Qur'an Mbak... dan juga sekarang sudah tinggal sama anak jadi lebih tenang.... Kalau ada apa-apa kan sudah ada anak di sini."

[\#5] "Dampaknya lebih positif... kegiatan saya jual pulsa, pengajian, doa dan shalat... justru saya begitu biar ndak teringat bapak..... Sekarang saya nganggur karena ndak boleh sama anak kerja... pun mboten kiat."

[\#6] “[harapan] yang diminta itu selalu sehat gitu aja..., selalu mendoakan yang sudah mendahului.... Anak-anak juga eman (peduli) pada saya.... [pokoknya] 
yang penting ikhlas... Anak-anak sudah pada besar dan senang, anak saya selalu... memikirkan... melindungi saya".

\section{Pengalaman Kesepian dan Kesejahteraan Subjektif}

Fitrah manusia adalah sebagai makhluk sosial, setiap manusia butuh untuk termasuk di dalam kelompok, terhubung dengan orang lain, serta membangun dan memelihara hubungan sosial. Mengutip kalimat Dalai Lama: "Kita manusia adalah makhluk sosial. Kita lahir ke dunia sebagai hasil dari tindakan manusia lain. Kita bertahan hidup karena bergantung pada orang lain. Suka atau tidak, tidak ada satu pun peristiwa dalam hidup kita yang tidak berhubungan dengan kegiatan orang lain. Untuk alasan inilah, sebagian besar dari kebahagiaan yang kita rasakan muncul dari dalam konteks keterhubungan kita dengan orang lain. ${ }^{24}$

Kedekatan dengan pasangan hidup memberikan dampak yang dapat diamati tidak hanya pada saat pasangan sedang bersama di satu tempat (berdekatan secara fisik), namun seseorang dapat menilai kedekatan juga pada saat pasangan tersebut terpisah dan salah satu atau keduanya merasa sangat kehilangan. Keterpisahan ini, sebagaimana kedekatan dapat terjadi secara fisik, emosional, atau keduanya. Meninggalnya pasangan merupakan bentuk keterpisahan yang paling menyedihkan, karena kedekatan telah direnggut secara tiba-tiba dan tidak bisa terjalin lagi untuk selamanya. Kesepian akan mudah muncul dalam diri orang yang ditinggalkan pasangannya, karena merasa tidak lagi memiliki ikatan emosional yang intim dan tidak mampu lagi menggantungkan diri secara emosional. Kedekatan dengan pasangan semasa hidup dapat menimbulkan perasaan kehilangan yang besar ketika pasangan meninggal dunia. Berdasarkan hasil penelitian Dahlberg, dkk, kehilangan pasangan (partner loss) merupakan faktor pemicu yang kuat dalam memunculkan kesepian pada lansia ${ }^{25}$

\footnotetext{
${ }^{24}$ Satici, Uysal, dan Deniz, "Linking social connectedness to loneliness: The mediating role of subjective happiness."

${ }^{25}$ Dahlberg, Agahi, dan Lennartsson, "Lonelier than ever? Loneliness of older people over two decades."
} 
Kesepian akan memunculkan reaksi. Seseorang yang sebelumnya telah menilai kesepiannya secara positif, bahwa kesepian tidak mengganggu aktivitas dan kualitas hidupnya, maka reaksi positif jugalah yang muncul. Reaksi positif ini ditunjukkan antara lain dengan menerima diri dan lingkungannya. Rasa penerimaan menunjukkan sejauh mana seseorang mengenal dan memahami batasan-batasan yang dimiliki dalam mengatasi diri atau lingkungan. Rasa ini memberikan kekuatan dan semangat pada seseorang untuk dapat bertahan hidup, karena merasa dirinya mampu mengatasi masalah dan harus bangkit menjalani hidup. Penerimaan dan semangat untuk bertahan inilah yang menjadikan seseorang mampu mengatasi kesepiannya.Kesepian dapat muncul sebagai hasil pemahaman yang salah terhadap situasi yang dialami sehingga dapat menghasilkan respon emosi, pikiran, maupun perilaku yang maladaptif. Secara kognitif, pemahaman yang keliru dapat diatasi dengan mengembangkan pemahaman baru sehingga menimbulkan dampak emosional yang lebih positif. Masi, dkk melakukan meta-analisis terhadap beberapa strategi intervensi untuk mengatasi kesepian. Hasil penelitiannya menunjukkan bahwa kesepian dapat diatasi paling baik dengan menggunakan strategi intervensi yang fokus menangani kognisi sosial yang maladaptif. ${ }^{26}$

Kesepian, sebagaimana dijelaskan sebelumnya, dapat timbul sebagai dampak kedekatan dengan pasangan saat masih hidup. Kedekatan, merupakan salah satu ciri penting interaksi sosial. Selain itu, dalam bermasyarakat tentunya pasangan hidup memiliki konektivitas dengan orang lain di sekitarnya. Hubungan antara konsep ini akan terlihat ketika pasangan hidup meninggal, suami/istri yang ditinggalkan akan memisahkan diri secara sosial dalam waktu tertentu. Hal ini dapat dipastikan akan mengganggu interaksi sosial yang dijalani sebelumnya, dan melahirkan kesepian sebagai imbas hilangnya konekstivitas seseorang dengan lingkungan sosialnya. Namun kemungkinan lain dapat muncul karena interaksi sosial akan bertahan dalam waktu yang lama karena keterikatan di dalamnya, sehingga jika kesepian melanda, bentuk interaksi sosial yang lain akan muncul, yaitu dukungan sosial

${ }^{26}$ Christopher M. Masi et al., "A Meta-Analysis of Interventions to Reduce Loneliness," Personality and Social Psychology Review 15, no. 3 (2011): 219-66, https://doi.org/10.1177/1088868310377394. 
yang akan mengurangi dampak kesepian. Hasil penelitian Poscia, dkk menunjukkan bahwa strategi intervensi yang paling signifikan menurunkan dampak kesepian adalah yang melibatkan lansia dalam kegiatan sosial seperti diskusi kelompok, mendekatkan lansia dengan tetangga, membentuk support group untuk lansia, dan mengikutsertakan lansia dalam kegiatan waktu luang (misalnya yang berhubungan dengan seni atau life style). ${ }^{27}$

Keenam subjek penelitian menyatakan sempat mengalami kesepian, namun perlahan mereka mampu menyesuaikan diri dan mengatasi tiap kali perasaan tersebut muncul. Beberapa hal yang muncul di dalam pernyataan subjek adalah bagaimana ia berusaha mengembangkan pemikiran positif bahwa kesepian dapat menjadi hal yang baik. Subjek juga berusaha menerima kondisinya yang hidup sendiri dan menjanda sebagai suatu suratan takdir dan ia berupaya mengatasi dampak negatif perasaan kesepian dengan mendekatkan diri kepada Allah. Berdasarkan penelitian Septiningsih, strategi coping tersebut menggunakan pendekatan perasaan/emosi (emotional-focused), dengan metode self control dan positive reappraisal. Self-control, dilakukan dengan mengatur perasaannya sendiri atau mengambil tindakan tertentu dalam menghadapi suatu masalah. Positif reappraisal yaitu mencoba menciptakan sebuah arti positif dalam proses perkembangan personalnya yang lebih diwujudkan dengan menggunakan nilai-nilai religius. ${ }^{28}$

Hasil penelitian Satici, dkk menunjukkan bahwa kesejahteraan subjektif memainkan peran sebagai faktor yang memediasi hubungan antara keterhubungan sosial dengan kesepian. Dengan kata lain, jika seseorang memiliki tingkat keterhubungan sosial yang tinggi, maka ia merasa bahagia karena jarang merasa kesepian. ${ }^{29}$ Kesimpulan ini sejalan dengan hasil penelitian terdahulu yang dilakukan oleh Diener \& Seligmanbahwa orang yang bahagia

${ }^{27}$ Andrea Poscia et al., "Interventions targeting loneliness and social isolation among the older people: An update systematic review," Experimental Gerontology 102 (2018): 133-44, https://doi.org/10.1016/j.exger.2017.11.017.

${ }^{28}$ Dyah Siti Septiningsih dan Tri Na'imah, "Kesepian pada Lanjut Usia: Studi tentang Bentuk, Faktor Pencetus dan Strategi Koping," Jurnal Psikologi 11, no. 2 (2012), https://doi.org/10.14710/JPU.11.2.9.

${ }^{29}$ Satici, Uysal, dan Deniz, "Linking social connectedness to loneliness: The mediating role of subjective happiness."308. 
memiliki hubungan sosial yang memuaskan dan jarang menghabiskan waktunya seorang diri. ${ }^{30}$ Lyubomirsky, dkk menemukan bahwa prediktor utama rasa kebahagiaan pada seseorang adalah jarang merasa kesepian, merasa puas dengan hubungan persahabatan, dan memiliki keterhubungan sosial. ${ }^{31}$ Sejalan dengan hasil penelitian Tian yang menunjukkan bahwa lansia yang mendapatkan dukungan sosial dan terlibat dalam interaksi sosial akan menghasilkan kemampuan untuk menilai diri secara lebih positif, dan dengan demikian akan membuat ia merasa tidak kesepian dan lebih bahagia. ${ }^{32}$

Pertanyaan paling penting dalam hidup adalah pertanyaan yang berhubungan dengan makna dan tujuan eksistensi manusia. Al-Quran menjelaskan bahwa manusia telah ditempatkan di bumi ini untuk memanfaatkan potensinya yang sangat besar agarmampu melakukan usaha sendiri dengan cara yang akan memenuhi tujuan hidupnya. ${ }^{33} \mathrm{Hal}$ ini tersirat dalam QS. al-Mulk [67]: 2 sebagai berikut.

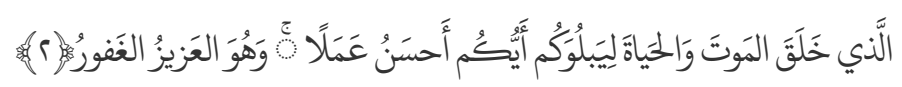

(Allah) Yang menciptakan mati dan hidup, untuk menguji kamu, siapa di antara kamu yang lebih baik amalnya. Dan Dia Mahaperkasa, Maha Pengampun..$^{34}$

Penelitian ini menunjukkan bahwa strategi coping yang dilakukan secara religius dengan mendekatkan diri kepada Allah membuat para janda lansia mampu memandang pengalaman kesepian yang dialami dengan lebih positif dan mencapai kebahagiaan di hari tua. Proses dan perjalanan hidup yang dialami sejak meninggalnya pasangan memang menimbulkan suatu perubahan dan dampak emosional yang signifikan, namun ternyata perilaku beribadah

${ }^{30}$ Satici, Uysal, dan Deniz, 307.

${ }^{31}$ Satici, Uysal, dan Deniz.

${ }^{32}$ Qian Tian, "Intergeneration social support affects the subjective well-being of the elderly: Mediator roles of self-esteem and loneliness," Journal of Health Psychology 21, no. 6 (2016): 1137-44, https://doiorg/10.1177/1359105314547245.

${ }^{33}$ Khurram Murad, In the Early Hours: Reflections on Spiritual and Self Development (Leicester, UK: Revival Publications, 1999), 83.

${ }^{34}$ QS. al-Mulk [67]: 2. 
(shalat, dzikir, dan mengaji) adalah upaya mendekatkan diri kepada Allah yang mampu menciptakan rasa syukur dan bahagia.

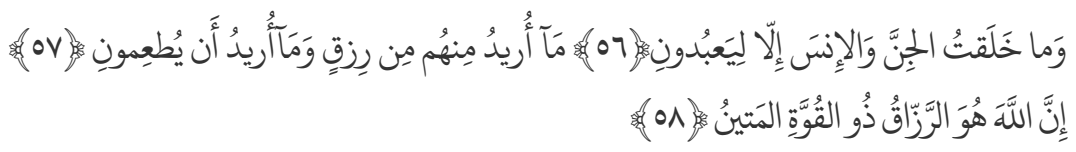

"[56] Aku tidak menciptakan jin dan manusia melainkan agar mereka beribadah kepada-Ku. [57] Aku tidak menghendaki rezeki sedikit pun dari mereka dan Aku tidak menghendaki agar mereka memberi makan kepada-Ku. [58] Sungguh Allah, Dialah Pemberi rezeki Yang Mempunyai Kekuatan lagi Sangat Kokoh." ${ }^{35}$

Al-Qur'an lebih lanjut menegaskanbahwa peran manusia di bumi adalah hidup untuk Penciptanya yang menghendaki dia untuk menyerahkan segalanya dan beribadah hanya kepada Allah. Ini bukan karena Allah dengan cara apa pun membutuhkan penyembahannya, tetapi karena manusia hanya perlu memuja Penciptanya dan tidak ada yang lain sehingga terhindar dari sifat yang merusak dan lalai, dan sehingga ia tidak hidup bertentangan dengan karakter intrinsiknya. Hanya dengan menjalani kehidupan seperti inilah, kehidupan manusia di dunia akan berada di jalan yang benar dan sejahtera, membawa kedamaian dan kebahagiaan, sebagaimana makna QS Adh-Dhuriyat: 56-58. ${ }^{36}$

\section{Kesimpulan dan Saran}

Interpretasi tentang pengalaman kesepian dan kesejahteraan subjektif yang telah dikemukakan di atas menghasilkan suatu kesimpulan mengenai pandangan dan reaksi seorang janda lansia terhadap kesepian dan bagaimana mereka mencapai kebahagiaan. Secara psikologis, esensi dari kesepian adalah kondisi di mana seseorang merasa kehilangan ciri penting dalam hubungan sosialnya. Ciri penting yang dimaksud adalah kedekatan dengan pasangan hidup yang terenggut oleh kematian. Kehilangan ini selanjutnya dapat diatasi dengan menumbuhkan semangat untuk bertahan hidup dan menjalin kembali interaksi sosial. Jika mampu mempertahankan keduanya, maka lansia akan

\footnotetext{
${ }^{35}$ QS. al-Dhāriyāt [51]: 56-58.

${ }^{36}$ Murad, In the Early Hours: Reflections on Spiritual and Self Development.
} 
mencapai kesejahteraan subjektif yang ditandai dengan perasaan bahagia dan bersyukur serta terciptanya pandangan hidup yang positif.

Saran peneliti untuk penelitian selanjutnya yang pertama tentunya berkaitan dengan jumlah subjek yang dilibatkan dapat ditambah agar mewakili beberapa karakteristik gender, demografis mauun sosial ekonomi. Pelibatan lebih banyak subjek diharapkan mampu menjadikan hasil penelitian untuk menjelaskan fenomena melainkan juga memiliki daya pembanding dalam menjelaskan fenomena pada subjek yang berbeda. Melihat banyaknya judul penelitian di Indonesia yang membahas tentang kesepian dan kesejahteraan subjektif pada lansia, peneliti melihat belum banyak yang fokus pada penemuan atau pengujian strategi intervensi yang tepat untuk mengatasi dampak emosional kesepian pada lansia. Penelitian ini dapat dikembangkan agar dapat menjadi strategi intervensi maupun promosi kesehatan mental usia lanjut.[s]

\section{Daftar Pustaka}

Afida, Nanik, S. Wahyuningsih, dan E. M. Sukamto. "Hubungan antara pemenuhan kebutuhan berafiliasi dengan tingkat depresi pada lansia di Panti Wredha." Anima: Indonesian Psychology Journal 15, no. 2 (2000): 180-195.

Badan Pusat Statistik Provinsi Jawa Tengah. "Profil Lansia Jawa Tengah 2016." Semarang: Badan Pusat Statistik Provinsi Jawa Tengah, 2017. https://jateng.bps.go.id/publication/2017/08/22/198c042d53836d78c3e 51277/profil-lansia-jawa-tengah--2016.html.

Dahlberg, Lena, Neda Agahi, dan Carin Lennartsson. "Lonelier than ever? Loneliness of older people over two decades." Archives of Gerontology and Geriatrics 75 (2018): 96-103. https://doi.org/10.1016/ J.ARCHGER.2017.11.004.

Hulme, W. Kesepian Sumber Ilham yang Kreatif. Terj. Staf Yayasan CLK. Jakarta: Cipta Loka Karya, 1993.

Hurlock, Elizabeth B. Psikologi Perkembangan: Suatu Pendekatan Sepanjang Rentang Kehidupan. Terj. Ridwan Max Sijabat. 5 ed. Jakarta: Erlangga, 2002. 
Linley, P. A., dan P. Joseph. Positive Psychology in Practice. New Jersey: John Wiley \& Sons, 2004.

Masi, Christopher M., Hsi-Yuan Chen, Louise C. Hawkley, dan John T. Cacioppo. "A Meta-Analysis of Interventions to Reduce Loneliness." Personality and Social Psychology Review 15, no. 3 (2011): 219-66. https://doi.org/ $10.1177 / 1088868310377394$.

Murad, Khurram. In the Early Hours: Reflections on Spiritual and Self Development. Leicester, UK: Revival Publications, 1999.

Poerwadarminta. "Bausastra Jawa, Poerwadarminta, 1939, \#75 (Bagian 18: NG) Sastra Jawa." Bausastra Jawa, 1939. https://www.sastra.org/bahasa-danbudaya/kamus-dan-leksikon/798-bausastra-jawa-poerwadarminta-193975-bagian-18-ng.

Poscia, Andrea, Jovana Stojanovic, Daniele Ignazio La Milia, Mariusz Duplaga, Marcin Grysztar, Umberto Moscato, Graziano Onder, Agnese Collamati, Walter Ricciardi, dan Nicola Magnavita. "Interventions targeting loneliness and social isolation among the older people: An update systematic review." Experimental Gerontology 102 (2018): 133-44. https://doi.org/10.1016/ j.exger.2017.11.017.

Pusat Data dan Informasi Kementerian Kesehatan Republik Indonesia. Analisis Lansia di Indonesia. Jakarta: Kementerian Kesehatan RI, 2017. http://www. pusdatin.kemkes.go.id/resources/download/pusdatin/lain-lain/Analisis Lansia Indonesia 2017.pdf.

Rathus, Spencer A., dan Jeffrey S. Nevid. Psychology and the Challenges of Life: Adjustment in The New Millenium. New York: John Wiley \& Sons, Inc., 2002.

Santrock, John W. Life-span Development. Jakarta: Erlangga, 2002.

Satici, Seydi Ahmet, Recep Uysal, dan M. Engin Deniz. "Linking social connectedness to loneliness: The mediating role of subjective happiness." Personality and Individual Differences, 2016, 306-10. https://doi.org/ 10.1016/j.paid.2015.11.035.

Schaie, K.Warner, dan Sherry L Willis. Adult Development and Aging. New York: Harper Collins Publisher, Inc., 1991.

Sears, David O., Jonathan L. Freedman, dan L. Anne Peplau. Psikologi Sosial. Terj. Michael Adryanto dan Savitri Soekrisno. Jakarta: Erlangga, 1999. 
Lucky Ade Sessiani

Septiningsih, Dyah Siti, dan Tri Na'imah. "Kesepian pada Lanjut Usia: Studi tentang Bentuk, Faktor Pencetus dan Strategi Koping." Jurnal Psikologi 11, no. 2 (2012). https://doi.org/10.14710/JPU.11.2.9.

Tian, Qian. "Intergeneration social support affects the subjective well-being of the elderly: Mediator roles of self-esteem and loneliness." Journal of Health Psychology 21, no. 6 (2016): 1137-44. https://doi.org/10.1177/ 1359105314547245. 